\title{
An ANN approach for predicting the cutting inserts performances of different geometries in hard turning
}

\author{
Senthilkumar, $\mathbf{N}^{\mathrm{a},{ }^{,},}$, Tamizharasan, T. ${ }^{\mathrm{b}}$, Anandakrishnan, $\mathrm{V} .{ }^{\mathrm{c}}$ \\ ${ }^{a}$ Adhiparasakthi Engineering College, Melmaruvathur, TamilNadu, India - 603319 \\ ${ }^{\mathrm{b}}$ TRP Engineering College, Irungalur, Tiruchirappalli, TamilNadu, India - 621105 \\ ${ }^{c}$ National Institute of Technology, Tiruchirappalli, TamilNadu, India - 620015
}

\begin{abstract}
A B S T R A C T
In this work an artificial intelligent (AI) technique viz. artificial neural network (ANN) is applied for predicting output responses such as wear occurring at the flank face of the cutting insert and the roughness of the machined workpiece's surface during the hard turning process. The experiments were designed using Taguchi's design of experiments (DoE) and suitable $\mathrm{L}_{18}$ orthogonal array (OA) was selected for the chosen parameters: cutting speed, feed rate, depth of cut, material hardness, cutting insert shape, relief angle, and nose radius. They are varied through three different levels. 18 different ISO designated cutting inserts were used for conducting the experiments on a CNC turning centre. An ANN model consisting of two hidden layers with 15 neurons each was modelled based on the complexity of the work. From the 18 experimental data, a set of 12 data was used for training the framed model and a set of 6 data for testing. An overall R-squared value of 0.9926 obtained during training the data showed the supremacy of the ANN technique. From the obtained results, it is obvious that the neural network models can be successfully used for predicting the output responses without performing the experiments.
\end{abstract}

\section{ARTICLE INFO}

Keywords:

Hard turning

Flank wear

Surface roughness

Artificial neural network

${ }^{*}$ Corresponding author: nskumar_1998@yahoo.co.in (Senthilkumar, N.)

\section{Article history:}

Received 21 January 2012

Revised 22 November 2013

Accepted 25 November 2013

\section{References}

[1] Astakhov, V.P. (2011). Machining of hard materials - Definitions and industrial applications, In: Davim, J. P. (ed.), Machining of hard materials, Springer, London, 1-32.

[2] Grzesik, W. (2008). Machining of hard materials, In: Paulo Davim, J. (ed.), Machining fundamentals and recent advances, Springer-Verlag London Limited, 97-126.

[3] Dixit, P.M., Dixit, U.S. (2008). Modeling of metal forming and machining processes by finite element and soft computing methods, Springer-Verlag London.

[4] Jackson, M.J., Robinson, G.M., Hyde, L.J., Rhodes, R. (2006). Neural image processing of the wear of cutting tools coated with thin films, Journal of Materials Engineering and Performance, Vol. 15, No. 2, 223-229, doi: $10.1361 / 105994906$ X95922.

[5] Özel, T., Karpat, Y., Figueira, L., Davim, J.P. (2007). Modelling of surface finish and tool flank wear in turning of AISI D2 steel with ceramic wiper inserts, Journal of Materials Processing Technology, Vol. 189, No. 1-3, 192-198, doi: 10.1016/j.jmatprotec.2007.01.021.

[6] Wang, X., Wang, W., Huang, Y., Nguyen, N., Krishnakumar, K. (2008). Design of neural network-based estimator for tool wear modeling in hard turning, Journal of Intelligence manufacturing, Vol. 19, No. 4, 383-396, doi: 10.1007/s10845-008-0090-8.

[7] Abburi, N.R., Dixit, U.S. (2006). A knowledge-based system for the prediction of surface roughness in turning process, Robotics and Computer-Integrated Manufacturing, Vol. 22, No. 4, 363-372, doi: 10.1016/j.rcim. 2005.08.002.

[8] Karayel, D. (2009). Prediction and control of surface roughness in CNC lathe using artificial neural network, Journal of Materials Processing Technology, Vol. 209, No. 7, 3125-3137, doi: 10.1016/j.jmatprotec.2008.07.023. 
[9] Nalbant, M., Gökkaya, H., Toktaş, İ., Sur, G. (2009). The experimental investigation of the effects of uncoated, PVD- and CVD-coated cemented carbide inserts and cutting parameters on surface roughness in CNC turning and its prediction using artificial neural networks, Robotics and Computer-Integrated Manufacturing, Vol. 25, No. 1, 211-223, doi: 10.1016/j.rcim.2007.11.004.

[10] Davim, J.P., Gaitonde, V.N., Karnik, S.R. (2008). Investigations into the effect of cutting conditions on surface roughness in turning of free machining steel by ANN models, Journal of Materials Processing Technology, Vol. 205, No. 1-3, 16-23, doi: 10.1016/j.jmatprotec.2007.11.082.

[11] Yilmaz, S., Arici, A.A., Feyzullahoglu, E. (2011). Surface roughness prediction in machining of cast polyamide using neural network, Neural Computing \& Applications, Vol. 20, No. 8, 1249-1254, doi: 10.1007/s00521-011-0557-y.

[12] Çaydaş, U., Hasçalık, A. (2008). A study on surface roughness in abrasive water jet machining process using artificial neural networks and regression analysis method, Journal of Materials Processing Technology, Vol. 202, No. 1-3, 574-582, doi: 10.1016/j.jmatprotec.2007.10.024.

[13] Asiltürk, İ., Çunkaș, M. (2011). Modeling and prediction of surface roughness in turning operations using artificial neural network and multiple regression method, Expert Systems with Applications, Vol. 38, No. 5, 5826-5832, doi: 10.1016/j.eswa.2010.11.041.

[14] Patowari, P.K., Saha, P., Mishra, P.K. (2010). Artificial neural network model in surface modification by EDM using tungsten-copper powder metallurgy sintered electrodes, The International Journal of Advanced Manufacturing Technology, Vol. 51, No. 5-8, 627-638, doi: 10.1007/s00170-010-2653-z.

[15] Sarkar, S., Mitra, S., Bhattacharyya, B. (2006). Parametric optimisation of wire electrical discharge machining of $\gamma$ titanium aluminide alloy through an artificial neural network model, International Journal of Advanced Manufacturing Technology, Vol. 27, No. 5-6, 501-508, doi: 10.1007/s00170-004-2203-7.

[16] Umbrello, D., Ambrogio, G., Filice, L., Shivpuri, R. (2008). A hybrid finite element method-artificial neural network approach for predicting residual stresses and the optimal cutting conditions during hard turning of AISI 52100 bearing steel, Materials \& Design, Vol. 29, No. 4, 873-883, doi: 10.1016/j.matdes.2007.03.004.

[17] Umbrello, D., Ambrogio, G., Filice, L., Shivpuri, R. (2007). An ANN approach for predicting subsurface residual stresses and the desired cutting conditions during hard turning, Journal of Materials Processing Technology, Vol. 189, No. 1-3, 143-152, doi: 10.1016/j.jmatprotec.2007.01.016.

[18] Walsh, R.A. (2001). Handbook of machining and metalworking calculations, McGraw-Hill, USA.

[19] Roy, R.K. (2001). Design of experiments using the Taguchi approach: 16 steps to product and process improvement, John Wiley \& Sons, Inc., USA.

[20] Senthilkumar, N., Tamizharasan, T. (2012). Impact of interface temperature over flank wear in hard turning using carbide inserts, Procedia Engineering, Vol. 38, 613-621, doi: 10.1016/j.proeng.2012.06.076.

[21] Tamizharasan, T., Senthilkumar, N. (2012). Analysis of surface roughness and material removal rate in turning using Taguchi's technique, In: Proceedings of IEEE - International Conference on Advances in Engineering, Science and Management, EGS Pillay Engineering College, Nagapattinam, 231-236.

[22] Nalbant, M., Gökkaya, H., Sur, G. (2007). Application of Taguchi method in the optimization of cutting parameters for surface roughness in turning, Materials \& Design, Vol. 28, 1379-1385, doi: 10.1016/j.matdes.2006.01.008.

[23] Venkata Rao, R. (2011). Advanced Modeling and Optimization of Manufacturing Processes: International Research and Development, Springer London, 10.1007/978-0-85729-015-1.

[24] Jafarian, F., Taghipour, M., Amirabadi, H. (2013). Application of artificial neural network and optimization algorithms for optimizing surface roughness, tool life and cutting forces in turning operation, Journal of Mechanical Science and Technology, Vol. 27, No. 5, 1469-1477, doi: 10.1007/s12206-013-0327-0.

[25] Siddhpura, A., Paurobally, R. (2013). A review of flank wear prediction methods for tool condition monitoring in a turning process, The International Journal of Advanced Manufacturing Technology, Vol. 65, No. 1-4, 371-393, doi: $10.1007 /$ s00170-012-4177-1.

[26] Natarajan, C., Muthu, S., Karuppuswamy, P. (2011). Prediction and analysis of surface roughness characteristics of a non-ferrous material using ANN in CNC turning, The International Journal of Advanced Manufacturing Technology, Vol. 57, No. 9-12, 1043-1051, doi: 10.1007/s00170-011-3343-1.

[27] Upadhyay, V., Jain, P.K., Mehta, N.K. (2013). In-process prediction of surface roughness in turning of Ti-6Al-4V alloy using cutting parameters and vibration signals, Measurement, Vol. 46, No. 1, 154-160, doi: 10.1016/ j.measurement.2012.06.002.

[28] Ahilan, C., Kumanan, S., Sivakumaran, N., Edwin Raja Dhas, J. (2013). Modeling and prediction of machining quality in CNC turning process using intelligent hybrid decision making tools, Applied Soft Computing, Vol. 13, No. 3, 1543-1551, doi: 10.1016/j.asoc.2012.03.071.

[29] Attanasio, A., Ceretti, E., Giardini, C. (2013). Analytical models for tool wear prediction during AISI 1045 turning operations, Procedia CIRP, Vol. 8, 218-223.

[30] Hristev, R.M. (1998). The ANN Book, Edition 1, GNU Public License, Ver. 2. 